\title{
POLITICS AND PRODUCTIVITY
}

\author{
PETER G. KLEIN and HUNG LUU*
}

\begin{abstract}
We use a stochastic frontier approach to study the effects of political and regulatory institutions on aggregate productivity in 39 countries from 1975 to 1990. We show that technical efficiency is positively related to policies supporting laissez-faire and political structures that promote policy stability. Moreover, models of technical efficiency incorporating both measures perform better than models including only one or the other. This suggests that economic performance depends not only on current policies but also on the confidence of market participants and outside investors that these policies will remain in place. (JEL O40, O30, H10, N40, D23)
\end{abstract}

\section{INTRODUCTION}

Economic studies of long-run performance are focusing increasingly on political, legal, financial, and social factors. Development is no longer regarded as a gradual, inevitable transformation from self-sufficiency to specialization and participation in the division of labor. Instead, progress follows the creation and evolution of institutions that support social and commercial relationships. The new institutional economics explains that growth requires that the potential hazards of trade (shirking, opportunism, risk, and so on) be controlled by institutions like secure property rights, reliable procedures for resolving disputes, and means of enforcing contracts in the absence of close social ties. These institutions reduce information costs, encourage capital formation and capital mobility, allow risks to be priced and shared, and otherwise facilitate cooperation (North and Thomas, 1973; North, 1990; Drobak and Nye, 1997; Levine, 1997). In particular, political authorities must

*We thank James Gwartney, Witold Henisz, Randall Holcombe, Robert Lawson, Knox Lovell, David Robinson, Dexter Samida, Chris Westley, and an anonymous referee for helpful comments; Kathrin Zoeller for research assistance; and Witold Henisz for supplying data. Klein thanks the University of Georgia Research Foundation for financial support.

Klein: Senior Fellow, Contracting and Organizations Research Institute, and Assistant Professor, Department of Agricultural Economics, University of Missouri, Columbia, MO 65203. Phone 1-573-882-7008, Fax 1-573-882-3958, E-mail pklein@missouri.edu

Luu: Analyst, Debt Capital Markets, Merrill Lynch Capital Markets Bank Ltd., 60311 Frankfurt, Germany. Phone 49-69-5899-5510, Fax 49-69-58994007, E-mail hung_luu@ml.com make credible commitments not to expropriate private resources once investments have been made. ${ }^{1}$

Despite widespread agreement that institutions matter, there is no consensus on how they should be incorporated into the analysis. Even the best empirical studies of productivity and growth treat institutional characteristics in an eclectic way. Barro's (1991) influential article, for example, uses the numbers of assassinations and revolutions per capita as proxies for political instability, finding these measures negatively correlated with growth and investment. Scully (1988) regresses growth rates on dummy variables derived from Gastil's (1982) ordinal rankings of political and economic liberty. King and Levine (1993a; 1993b; 1993c) derive various measures of the quality of financial intermediaries and show that these measures are good predictors of growth.

This article presents a different approach to analyzing the relationship between institutions and aggregate economic performance. Following the modern productivity literature (see, for example, Fried et al., 1993), we model economic performance with a stochastic production frontier. Frontier analysis is a form

1. For general surveys of the new institutional economics see Furubotn and Richter (1997) and Klein (2000). North (1991) summarizes the literature as it applies specifically to economic development.

\section{ABBREVIATIONS}

EF: Economic Freedom

GDP: Gross Domestic Product

PC: Policy Constraints

SOE: State-Owned Enterprise 
of benchmarking. It analyzes a group of branches, firms, nations, or other units by identifying best practices and evaluating each member's performance relative to the best-practice frontier. The results produce not only qualitative rankings of the group members but also numerical efficiency scores that can be used to assess the effects of various policies and characteristics. For this reason, frontier analysis is well suited for studying the effects of legal and political institutions on the economic performance of nations.

To capture institutional factors, we use two comprehensive indexes of legal, regulatory, and political conditions. Working with a broad sample of countries from 1975 to 1990, we incorporate a widely used measure of economic freedom along with a new measure of policy stability to represent a country's institutional environment. The new institutional economics suggests that countries with high levels of economic freedom (protection of private property rights, respect for the rule of law, an unhampered price system, and so on) and policy stability (commitment not to change the rules of the game ex post) will be closer to the best-practice frontier.

In our model, economic freedom and policy stability affect economic performance by enhancing technical efficiency. In other words, these institutions do not alter the state of technology, but they allow producers to squeeze more out of current technology. For instance, countries with more stable policies attract more foreign investment than countries with less stable policies, ceteris paribus; this leads to increased competition among producers, which in turn brings efficiency gains. Similarly, countries with lower taxes, milder regulatory burdens, lower inflation, fewer restrictions on foreign ownership, and so on are likely to produce output more efficiently than countries with policies that restrict production, inhibit capital formation, and reduce competition. $^{2}$

Our results strongly support the claim that the institutional environment affects technical efficiency. Specifically, we find that both economic freedom and policy stability are

2. We are using the term technical efficiency broadly, defining it to include anything that brings a country closer to the best-practice frontier. This could include improvements in allocative as well as productive efficiency. Of course, a more general model would also explore the relationship between institutions and the state of technology. highly significant determinants of a country's relationship to the best-practice frontier. Moreover, models of technical efficiency incorporating both measures perform better than models including only one or the other. This suggests that economic performance depends not only on current policies but on the confidence of market participants and outside investors that these policies will remain in place. Economic freedom is important, but even more so when combined with policy stability and vice versa. These results hold whether a composite measure or individual components of economic freedom are used.

The remainder of the article is organized as follows. Section II outlines the stochastic frontier model and describes the data. Section III presents results using the composite measure of economic freedom. Section IV explores the effects of individual components of economic freedom. Section $\mathrm{V}$ examines our results for endogeneity, and section VI concludes.

\section{METHODS AND DATA}

We model the best-practice frontier for our sample countries as a stochastic production frontier. The concept of a stochastic production frontier was proposed independently by Aigner et al. (1977) and Meeusen and van den Broeck (1977). The original specification involved a production frontier for crosssectional data with an error term consisting of two components, one to account for random error and another to account for technical inefficiency. The original model was later extended to incorporate time-series variation and the prediction of technical efficiency scores by appropriate explanatory variables. We use a panel data version of Battese and Coelli $(1993 ; 1995)$ that allows simultaneous estimation of technology parameters of a stochastic production frontier and the parameters of an inefficiency model.

Our specification proceeds as follows. Suppose producer $i$ at time $t$ uses a vector of inputs $x_{i t} \in \mathbf{R}_{+}^{N}$ to produce scalar output $y_{i t} \in \mathbf{R}_{+}$with technology

$$
y_{i t}=f\left(x_{i t}, \beta\right) \exp \left(v_{i t}-u_{i t}\right) \text {, }
$$

and

$$
u_{i t}=z_{i t} \cdot \delta+w_{i t} \geq 0,
$$


where $i=1 \ldots, I$ indexes producers, $t=1 \ldots, T$ indexes time, $f$ denotes the production frontier, and $\beta$ is a vector of technology parameters to be estimated. The $v_{i t}$ s represent random errors and are assumed to be iid $N\left(0, \sigma_{v}^{2}\right)$. Technical inefficiency is captured by the $u_{i t} \mathrm{~s}$, which are assumed to be independently distributed as $N^{+}\left(z_{i t} \cdot \delta, \sigma_{u}^{2}\right)$. They are also assumed to be distributed independently of the $v_{i t} \mathrm{~s}$. The parameter $z_{i t}$ is a vector of explanatory variables associated with technical inefficiency, and $\delta$ is a vector of unknown parameters to be estimated. The $w_{i t}$ s are defined by the normal distribution with mean zero and variance $\sigma_{u}^{2}$ and are truncated at $-z_{i t} \cdot \delta$, which ensures that $u_{i t} \geq 0$. The log-likelihood is expressed in terms of the variance parameters $\sigma^{2} \equiv$ $\sigma_{u}^{2}+\sigma_{v}^{2}$ and $\gamma=\sigma_{u}^{2} / \sigma^{2}$. The variance ratio $\gamma$, bounded by zero and one, can be interpreted as an inefficiency indicator. As $\gamma$ goes to zero, variation in $\sigma^{2}$ is attributed entirely to noise. As $\gamma$ goes to one, variation in $\sigma^{2}$ is attributed entirely to inefficiency. ${ }^{3}$

In this context, technical efficiency is defined as the ratio of observed to maximum feasible output. Formally,

$$
\begin{aligned}
T E_{i t} & =y_{i t} /\left[f\left(x_{i t}, \beta\right) \exp \left(v_{i t}\right)\right]=\exp \left(-u_{i t}\right) \\
& =\exp \left(-z_{i t} \cdot \delta-w_{i t}\right)
\end{aligned}
$$

where $T E_{i t}$ denotes technical efficiency of producer $i$ in period $t$. Battese and Coelli (1993) show that the minimum-mean-squared error predictor of technical efficiency is given by

$$
E\left[\exp \left(-u_{i t}\right) \mid v_{i t}-u_{i t}\right]
$$

Maximum-likelihood estimates for the parameters of both the stochastic production frontier and the technical inefficiency model can be obtained from the computer program FRONTIER 4.1 (Coelli, 1996). ${ }^{4}$

3. See Battese and Coelli (1993) for the derivation of the log-likelihood.

4. Scully (1988) also uses a frontier approach to examine the effects of social institutions. He shows that ordinal rankings of political, civil, and economic liberty positively affect a country's ability to convert capital per worker into output per worker. However, Scully's two-stage approach poses problems. In the first stage he estimates a deterministic production frontier and predicts technical efficiency scores for each country under the assumption that the technical efficiency scores are identically distributed.
Our data on inputs and outputs are taken from the Penn World Table (Summers and Heston, 1991), which provides income and expenditure data for about 150 countries from 1950 to the present. The expenditure entries are denominated in common prices in a common currency to permit real comparisons across countries and over time.

A key advantage of our approach over others typically used in the growth literature is that we use output levels, rather than growth rates, to estimate our stochastic frontiers. The Penn World Table was designed to compare income levels using "international prices" to adjust for differences in the purchasing power of currencies. It turns out that these international prices most closely resemble those of Hungary. Nuxoll (1994, 1423) notes that use of these prices tends to overstate growth rates for countries wealthier than Hungary and to understate growth rates for countries less wealthy than Hungary. He writes (1434) that "probably the ideal is to use Penn World Table numbers for levels and the usual national-accounts data for growth rates." Our stochastic frontier approach avoids such bias by focusing on input and output levels, not growth rates. ${ }^{5}$

To capture the role of institutions, we begin with the composite measure of economic freedom (EF) provided by Gwartney et al. (2000). In their definition, "Individuals have economic freedom when: (a) their property acquired without the use of force, fraud, or theft is protected from physical invasions by others and (b) they are free to use, exchange, or give their property to another as long as their actions do not violate the identical rights of others." Working with this definition, Gwartney et al. construct an index measuring how strongly these rights are protected across a broad sample of countries over time. The composite EF

The second stage involves a regression of the predicted technical efficiency scores on three measures of liberty. But this is inconsistent with the initial assumption of identically distributed technical efficiency scores. Our formulation avoids this problem with a one-stage approach that estimates the technology parameters of the stochastic production frontier and the parameters of the inefficiency model together.

5. Temple $(1999,119)$ also discusses problems caused by confusing income levels with growth rates. Reliance on data from the Penn World Table may explain why so many studies have failed to find convergence in growth rates among countries. 
measure consists of 23 components allocated to four major areas: (1) money and inflation, (2) government operations and regulations, (3) takings and discriminatory taxation, and (4) international trade. The composite measure represents the degree to which government policy fosters savings, foreign investment, and commercial and industrial development. ${ }^{6}$ The data are provided in a series of five-year cross-sections from 1970 to $2000 .^{7}$

We interpret $E F_{t}$ as characterizing the policy status quo in year $t$. Economic development clearly requires desirable policies, but it also requires policy stability; investors must believe that desirable policies are likely to remain in place. We therefore add to our model a new measure of policy constraints (PC) developed by Henisz (2000a). ${ }^{8}$ This measure, derived from a spatial model of political interaction, describes how easily the status quo can be changed. It is made up of two elements: the number of potential veto points in the political system and the current alignment of political interests, defined as the degree to which political actors agree on the desired policy, whatever that policy may be. ${ }^{9}$ Veto points make it difficult to change the status quo by administrative or executive fiat; alignment of interests makes it unlikely that political actors will want to change the status quo.

Henisz suggests two channels through which policy constraints affect economic performance. First, by reducing the risk of wealth expropriation through arbitrary changes in tax, regulatory, or other policy areas, stable policies encourage foreign investment, especially where relationship-specific investments

6. A value of ten represents very high $\mathrm{EF}$ and a value of zero very low EF. Though the aggregate country ranking is given on this ten-point scale, the individual components are derived from quantitative measurements, not subjective, qualitative assessments. For this reason, the data are unlikely to be biased in favor of a positive relationship between economic freedom and economic performance (as would be the case if researchers tended to assign high EF rankings to more prosperous countries). See also our discussion of the individual components.

7. Other papers on institutions and growth using the Gwartney et al. data include Easton and Walker (1997), Dawson (1998; 2002), Gwartney et al. (1998; 1999), Norton (1998), Ayal and Karras (1998), La Porta et al. (1999), Ali and Crain (2002), and Carlsson and Lundström (2002).

8. The PC measure is also used in Henisz (2000b) and Henisz and Zelner (2001).

9. A value of one represents very high policy stability and a value of zero very low policy stability. are at stake. Second, under stable policy regimes, fewer resources tend to be spent in rent-seeking activities, freeing those resources to create wealth. We consider the effects of EF and PC both separately and together, presuming that EF should be more valuable in the presence of PC, and PC should be more valuable in the presence of EF. ${ }^{10}$

Drawing from these sources and eliminating observations with missing data, we construct a balanced panel of 39 countries for the years $1975,1980,1985$, and 1990 with a total of 156 observations. ${ }^{11}$ (The list of countries is included as Appendix Table A1.) Real gross domestic product (GDP) per worker and capital stock per worker in 1985 international prices are taken from Summers and Heston (1991). Summary statistics for all variables are provided in Table 1.

Are high levels of EF associated with high levels of PC? In our sample the correlation between EF and PC is 0.538, smaller than we initially expected. Some countries, like the United States, Canada, and Switzerland, score high on both measures, whereas others, like Turkey, Iran, and Syria, score low on both. However, EF and PC do not necessarily go together. Israel, Portugal, and Spain rank high on PC but low on EF; these countries have very stable policies, but the content of those policies inhibits efficient resource allocation through markets. Guatemala, by contrast, scores high on EF but low on PC. Guatemala has relatively laissez-faire policies but provides investors and entrepreneurs little assurance that those policies will remain in place.

10. Policy stability should not be confused with political stability. Political stability refers to the likelihood that the current regime will remain in power. Zaire under Mobutu Sese Seko was an example of a country with a highly stable political regime but increasingly arbitrary policies. Similarly, policy stability does not measure political freedom - an extended franchise, the right to form political parties, an independent press, and so on. In our framework, such political rights affect productivity only to the extent that they affect economic freedom. For more on the relationship between political and economic freedom see the classic treatments by Mises (1927), Hayek (1944), and Friedman (1962).

11. The Penn World Table contains data on 152 countries, but not all variables are available in all four years. Henisz's data set on political constraints includes the same 152 countries, and the Gwartney, et al. data include from 83 to 123 countries, depending on the year, though some individual components of EF are missing in particular years. Our panel includes the 39 countries for which all necessary variables were available in all four years. 
TABLE 1

Summary Statistics

\begin{tabular}{|c|c|c|c|c|c|c|c|}
\hline Variable & Description & Source & Min. & Max. & Mean & Median & SD \\
\hline RGDP/worker & $\begin{array}{l}\text { Real GDP per worker in } 1985 \\
\text { international prices }(\$)\end{array}$ & $\begin{array}{l}\text { Summers and } \\
\text { Heston (1991) }\end{array}$ & 1,863 & 36,771 & 17,718 & 18,615 & 9,391 \\
\hline Capital/worker & $\begin{array}{l}\text { Capital per worker in } 1985 \\
\text { international prices }(\$)\end{array}$ & $\begin{array}{l}\text { Summers and } \\
\text { Heston (1991) }\end{array}$ & 553 & 73,459 & 19,860 & 18,733 & 14,419 \\
\hline Economic freedom & $\begin{array}{l}\text { Degree to which government } \\
\text { respects property rights and } \\
\text { promotes free trade. Ten } \\
\text { represents a high level of } \\
\text { economic freedom; zero } \\
\text { represents a low level. }\end{array}$ & $\begin{array}{l}\text { Gwartney et al. } \\
(2000)\end{array}$ & 2.00 & 7.80 & 4.84 & 4.70 & 1.42 \\
\hline Policy constraints & $\begin{array}{l}\text { Ease of changing current policy } \\
\text { regime. One represents highly } \\
\text { stable government; zero } \\
\text { represents highly unstable } \\
\text { government. }\end{array}$ & $\begin{array}{l}\text { Henisz (2000a; } \\
\text { 2000b) }\end{array}$ & 0.00 & 0.89 & 0.52 & 0.73 & 0.33 \\
\hline \multicolumn{8}{|c|}{ Individual components of economic freedom (from Gwartney et al. [2000]): } \\
\hline Inflation & $\begin{array}{l}\text { Difference between annual } \\
\text { growth of M1 and potential real } \\
\text { GDP }\end{array}$ & Table I-A & -2.90 & 690.20 & 30.54 & 10.80 & 86.88 \\
\hline $\begin{array}{l}\text { Government } \\
\text { spending }\end{array}$ & $\begin{array}{l}\text { Government consumption as } \\
\text { percent of total consumption }\end{array}$ & Table II-A & 5.60 & 40.20 & 15.87 & 15.55 & 5.83 \\
\hline SOEs & Role and presence of SOEs & Table II-B & 0 & 8 & 4.55 & 4.00 & 2.06 \\
\hline Foreign money & $\begin{array}{l}\text { Right to own foreign currency } \\
\text { domestically }\end{array}$ & Table I-C & 0 & 10 & 6.15 & 10.00 & 4.88 \\
\hline $\begin{array}{l}\text { Foreign capital } \\
\text { transactions }\end{array}$ & $\begin{array}{l}\text { Freedom to engage in capital } \\
\text { transactions with foreigners }\end{array}$ & Table IV-D & 0 & 10 & 3.78 & 2.00 & 3.19 \\
\hline Foreign account & $\begin{array}{l}\text { Right to own bank account } \\
\text { abroad }\end{array}$ & Table I-D & 0 & 10 & 4.49 & 0.00 & 4.99 \\
\hline Conscription & $\begin{array}{l}\text { Use of conscripts to obtain } \\
\text { military personnel }\end{array}$ & Table III-C & 0 & 10 & 2.55 & 0.00 & 4.37 \\
\hline Taxes on IT & $\begin{array}{l}\text { Average tax rate on } \\
\text { international trade }\end{array}$ & Table IV-A & 0.00 & 24.19 & 4.11 & 2.83 & 4.48 \\
\hline Trade sector & $\begin{array}{l}\text { Actual size of trade sector minus } \\
\text { expected size (percent) }\end{array}$ & Table IV-C & -69.97 & 116.93 & 8.00 & 5.48 & 33.39 \\
\hline $\begin{array}{l}\text { Black-market } \\
\text { premium }\end{array}$ & $\begin{array}{l}\text { Difference between official and } \\
\text { black-market exchange rates } \\
\text { (percent) }\end{array}$ & Table IV-B & 0.00 & $2,197.00$ & 32.04 & 2.00 & 184.34 \\
\hline
\end{tabular}

Notes: Pooled data from 1975, 1980, 1985, and 1990. $N=156$.

\section{BASIC RESULTS}

We employ a Cobb-Douglas stochastic production frontier in logarithmic form:

$$
\begin{aligned}
\ln y_{i t}= & \beta_{0}+\beta_{1} \ln x_{i t}+\sum_{t=2}^{4} \eta_{t} D_{t} \\
& +\sum_{i=2}^{39} \lambda_{i} D_{i}+v_{i t}-u_{i t},
\end{aligned}
$$

where $\ln y_{i t}$ is the natural $\log$ of real GDP per worker for country $i$ in period $t, \ln x_{i t}$ is the natural $\log$ of capital stock per worker for country $i$ in period $t, D_{t}$ is a time dummy for period $t$ intended to capture technical change (see Baltagi and Griffin, 1988), $D_{i}$ is a country dummy for country $i$ to control for unobserved heterogeneity, and $v_{i t}$ and $u_{i t}$ are defined as before. $^{12}$

To explore the effects of EF and PC on productivity we use four specifications of the

12. We chose this functional form because scale effects are unlikely to matter at this level of aggregation and because our focus lies on the inefficiency component of the model. As a robustness check, we also regressed the natural $\log$ of real GDP on the natural log of labor and the natural log of capital stock to allow for variable returns to scale. The corresponding results (not reported here) are similar to the results reported in this section. 
TABLE 2

Effects of Economic Freedom and Policy Constraints on Technical Efficiency

\begin{tabular}{|c|c|c|c|c|c|}
\hline \multirow[b]{2}{*}{ Parameter } & \multirow[b]{2}{*}{ Variable } & \multicolumn{4}{|c|}{ Specification } \\
\hline & & $\mathbf{I}$ & II & III & IV \\
\hline \multirow[t]{2}{*}{$\beta_{0}$} & Constant & $2.974^{* * *}$ & $4.206^{* * *}$ & $3.357^{* * *}$ & $3.361^{* * *}$ \\
\hline & & $(0.5640)$ & $(0.5614)$ & $(0.4436)$ & $(0.1295)$ \\
\hline \multirow[t]{2}{*}{$\beta_{1}$} & Capital/worker & $0.756^{* * *}$ & $0.599^{* * *}$ & $0.712^{* * *}$ & $0.720^{* * *}$ \\
\hline & & $(0.0609)$ & $(0.0613)$ & $(0.0484)$ & $(0.0130)$ \\
\hline \multirow[t]{2}{*}{$\delta_{0}$} & Constant & $0.790^{* * *}$ & $0.120^{* * *}$ & $0.925^{* * *}$ & $0.887^{* * *}$ \\
\hline & & $(0.0510)$ & $(0.0460)$ & $(0.0544)$ & $(0.0974)$ \\
\hline \multirow[t]{2}{*}{$\delta_{1}$} & $\mathrm{EF}$ & $-0.159^{* * *}$ & - & $-0.198^{* * *}$ & $-0.150^{* * *}$ \\
\hline & & $(0.0109)$ & & $(0.0154)$ & $(0.0214)$ \\
\hline \multirow[t]{2}{*}{$\delta_{2}$} & $\mathrm{PC}$ & - & $-0.571^{* * *}$ & $-0.333^{* * *}$ & $-0.360^{* *}$ \\
\hline & & & $(0.0985)$ & $(0.0596)$ & $(0.2160)$ \\
\hline \multirow[t]{2}{*}{$\delta_{3}$} & $\mathrm{EF} \cdot \mathrm{PC}$ & - & - & - & -0.001 \\
\hline & & & & & $(0.0446)$ \\
\hline \multirow[t]{2}{*}{$\sigma^{2}$} & & $0.016^{* * *}$ & $0.034^{* * *}$ & $0.031^{* * *}$ & $0.022^{* * *}$ \\
\hline & & $(0.0011)$ & $(0.0035)$ & $(0.0024)$ & $(0.0011)$ \\
\hline \multirow[t]{2}{*}{$\gamma$} & Inefficiency indicator & $0.999^{* * *}$ & $0.999^{* * *}$ & $0.999^{* * *}$ & $0.999^{* * *}$ \\
\hline & & $(0.0001)$ & $(0.0001)$ & $(0.0001)$ & $(0.0001)$ \\
\hline Log-likelihood & & 177.161 & 196.202 & 208.476 & 191.280 \\
\hline
\end{tabular}

Notes: Maximum-likelihood estimates for stochastic production frontier with inefficiency component. Pooled data from 1975, 1980, 1985, and 1990. $N=156$. Country and year fixed effects not reported. Standard errors given in parentheses.

${ }^{* * *},{ }^{* *}$, and ${ }^{*}$ represent statistical significance at the $1 \%, 5 \%$, and $10 \%$ levels, respectively.

technical inefficiency component:

$$
\begin{gathered}
u_{i t}=\delta_{0}+\delta_{1} E F_{i t}+w_{i t} \\
u_{i t}=\delta_{0}+\delta_{1} P C_{i t}+w_{i t} \\
u_{i t}=\delta_{0}+\delta_{1} E F_{i t}+\delta_{2} P C_{i t}+w_{i t} \\
u_{i t}=\delta_{0}+\delta_{1} E F_{i t}+\delta_{2} P C_{i t} \\
+\delta_{3} E F \cdot P C+w_{i t} .
\end{gathered}
$$

The first specification includes only EF as a source of inefficiency, the second includes only PC, the third includes both, and the fourth adds an interaction term. Table 2 provides parameter estimates for all four specifications.

The results strongly support the idea that EF and PC are important determinants of technical efficiency. The elasticity of real GDP per worker with respect to capital per worker, $\beta_{1}$, ranges from 0.599 to 0.712 . The inefficiency indicator, $\gamma$, is very close to one and highly significant, implying that nearly all the variation in $\sigma^{2}$ can be attributed to inefficiency. In the technical inefficiency component of the model, the key parameters $\delta_{1}$ and $\delta_{2}$ (the coefficients on EF and PC, respectively) have the expected signs and are highly significant: The higher the EF and the higher the PC, the less inefficient the country in converting capital per worker into real GDP per worker. The coefficient on the interaction term also has the expected sign, though it is not significant. ${ }^{13}$

13. As discussed in note $10, \mathrm{PC}$ is a measure of policy stability, not political stability. However, to check the robustness of our results, we experimented with an additional set of specifications, including an additional control variable, the average annual number of revolutions and coups during the previous five years (the most common proxy for political stability used in the growth literature). The data were obtained from Arthur Banks's Cross National Time-Series Data Archive. The results (not reported here) were virtually identical to those reported in Table 2. PC and EF retain the expected signs and significance levels, their point estimates are about the same as before, and the new variable is not statistically significant. This suggests that dramatic regime changes are important only to the extent that they affect policy stability and economic freedom. 
Likelihood ratio tests suggest focusing on specification (7). The estimated coefficient on $\mathrm{PC}$ in this specification is -0.333 . Mean technical efficiency for the sample is 0.8904 , which implies that mean $u_{i t}$ is 0.116 . If the mean PC score were one-third of a standard deviation ( 0.11 units or $21 \%$ ) above its current level, ceteris paribus, the mean $u_{i t}$ would fall by $-0.333 \cdot 0.11=-0.0337$ to -0.0794 . In turn, mean technical efficiency would rise to 0.9237. Similarly, if mean EF were one-third of a standard deviation ( 0.473 units or $10 \%)$ above its current level, ceteris paribus, mean $u_{i t}$ would fall by $-0.198 \cdot 0.473=-0.0937$ to -0.0223 . Mean technical efficiency would then rise substantially to 0.9780 , eliminating almost all waste! Of course, these quantitative statements should be interpreted with caution, because it is unclear what constitutes a unit of EF or PC. Nonetheless, the results strongly support the proposition that EF and PC enhance economic growth through technical efficiency gains.
This exercise also sheds light on the debate about the rise of the so-called East Asian tigers. A World Bank (1993) study attributed the impressive growth rates of Taiwan, South Korea, and Thailand from 1960 to 1990 to high rates of productivity growth, dubbing their strong economic performance the East Asian miracle. Young (1994), by contrast, suggested that the major source of their economic growth was increased utilization of capital and labor, not productivity growth. Krugman (1994) popularized the idea that East Asian growth was no miracle, claiming that higher output was driven merely by an increase in inputs. Without productivity growth, of course, output growth cannot be sustained for long.

Table 3 provides the raw data and technical efficiency scores for South Korea, Taiwan, Thailand, and eight other countries in the sample. South Korea, Taiwan, and Thailand all show significant improvement in technical efficiency from 1975 to 1990 . South Korea and

TABLE 3

The Asian Tigers and Selected Benchmarks

\begin{tabular}{|c|c|c|c|c|c|c|c|c|c|}
\hline Country & Year & $\begin{array}{l}\text { Real GDP } \\
\text { per Worker }\end{array}$ & $\begin{array}{c}\text { Capital per } \\
\text { Worker }\end{array}$ & $\begin{array}{l}\text { Technical } \\
\text { Efficiency }\end{array}$ & $\begin{array}{c}\text { Change }(\%) \\
\text { (Rank) }\end{array}$ & EF & $\begin{array}{c}\text { Change (\%) } \\
\text { (Rank) }\end{array}$ & PC & $\begin{array}{c}\text { Change }(\%) \\
\text { (Rank) }\end{array}$ \\
\hline South Korea & 1975 & 6,245 & 6,533 & 0.742 & & 4.00 & & 0.00 & \\
\hline South Korea & 1990 & 16,022 & 17,995 & 1.000 & $2.15(1)$ & 5.10 & $1.10(19)$ & 0.48 & $0.48(1)$ \\
\hline Taiwan & 1975 & 7,657 & 8,451 & 0.849 & & 4.90 & & 0.72 & \\
\hline Taiwan & 1990 & 18,409 & 25,722 & 0.999 & $1.17(9)$ & 6.10 & $1.20(15)$ & 0.71 & $-0.01(35)$ \\
\hline Thailand & 1975 & 3,371 & 2,385 & 0.772 & & 4.60 & & 0.28 & \\
\hline Thailand & 1990 & 6,754 & 4,912 & 0.999 & $1.86(2)$ & 6.20 & $1.60(10)$ & 0.35 & 0.07 (13) \\
\hline Chile & 1975 & 9,173 & 6,907 & 0.766 & & 2.80 & & 0.67 & \\
\hline Chile & 1990 & 11,854 & 9,543 & 0.849 & $0.73(12)$ & 6.10 & $3.30(1)$ & 0.71 & $0.04(15)$ \\
\hline India & 1975 & 2,069 & 1,259 & 0.747 & & 3.00 & & 0.20 & \\
\hline India & 1990 & 3,235 & 1,946 & 0.926 & $1.54(6)$ & 3.70 & $0.70(23)$ & 0.45 & $0.25(7)$ \\
\hline Portugal & 1975 & 10,354 & 7,461 & 0.777 & & 2.40 & & 0.67 & \\
\hline Portugal & 1990 & 16,637 & 11,819 & 0.972 & $1.61(4)$ & 4.10 & $1.70(9)$ & 0.75 & $0.08(12)$ \\
\hline Iran & 1975 & 20,388 & 6,696 & 0.996 & & 4.90 & & 0.00 & \\
\hline Iran & 1990 & 11,400 & 15,548 & 0.330 & -7.59 (39) & 3.20 & $-1.70(39)$ & 0.00 & $0.00(20)$ \\
\hline Nigeria & 1975 & 3,067 & 553 & 0.993 & & 3.20 & & 0.00 & \\
\hline Nigeria & 1990 & 2,082 & 702 & 0.615 & $-3.37(38)$ & 3.30 & $0.10(35)$ & 0.00 & $0.00(20)$ \\
\hline Syria & 1975 & 14,804 & 9,512 & 0.802 & & 3.90 & & 0.00 & \\
\hline Syria & 1990 & 15,871 & 14,994 & 0.671 & $-1.26(34)$ & 3.20 & $-0.70(37)$ & 0.00 & $0.00(20)$ \\
\hline Argentina & 1975 & 16,043 & 9,445 & 0.826 & & 3.10 & & 0.00 & \\
\hline Argentina & 1990 & 13,406 & 11,244 & 0.658 & $-1.61(35)$ & 3.40 & $0.30(32)$ & 0.41 & $0.41(3)$ \\
\hline Peru & 1975 & 10,486 & 8,710 & 0.952 & & 3.10 & & 0.00 & \\
\hline Peru & 1990 & 6,847 & 8,796 & 0.667 & $-2.51(37)$ & 3.40 & $0.30(32)$ & 0.38 & $0.38(4)$ \\
\hline
\end{tabular}

Notes: Technical efficiency scores and raw data for South Korea, Taiwan, Thailand, and eight other countries in the sample. Real GDP per worker and capital per worker measured in 1985 international prices. 
Thailand had technical efficiency growth rates of $2.15 \%$ and $1.86 \%$ per year, respectively, the highest efficiency growth rates in our sample. Taiwan ranked ninth with average annual efficiency growth of $1.17 \%$ over the same period.

Moreover, the raw data reveal that during this period these three countries experienced substantial improvements in EF, PC, or both. For the entire sample, the mean increase in PC between 1975 and 1990 was 0.09 units, and the mean increase in EF over the same period was 0.95 units. South Korea had the highest increase in PC, 0.48 units, along with an above-average increase in EF of 1.1 units (19th best). Similarly, Thailand had an increase in PC of 0.07 units (13th highest) and an increase in EF of 1.6 units (10th highest). Taiwan appears less impressive, with a 0.01 unit decrease in PC (35th best) and a 1.2-unit increase in EF (12th best). However, Taiwan started with a high 1975 PC score of 0.72 , which leaves little room for improvement. In short, our results suggest that the South Korean, Taiwanese, and Thai economies expanded not only through capital accumulation but also through productivity growth fostered by policies and institutions that increased economic freedom and improved policy stability.

This result is not exclusive to the East Asian tigers. Other countries with substantial increases in EF and PC leading to improvements in technical efficiency include India, Chile, and Portugal. Like South Korea, India achieved substantial improvements in PC ( 0.25 units, 7 th best in the sample $)$ and EF (0.7 units, 21 st best), and witnessed a corresponding increase in technical efficiency of $1.54 \%$ per year (6th best). Like Taiwan, Chile and Portugal maintained high levels of PC during the 1975-90 period while also increasing EF by 3.3 units (best in the sample) and 1.7 units (9th best), respectively. They simultaneously experienced annual technical efficiency growth rates of 0.73 (12th best) and 1.61 (4th best), respectively.

By contrast, consider Iran, Nigeria, and Syria. These countries experienced technical efficiency declines of $7.59 \%, 3.37 \%$, and $1.26 \%$, respectively. Our analysis suggests that these productivity losses were due to reductions in EF. All three countries rank at the bottom in EF change (Iran is worst at -1.70 , Syria third worst at -0.70 , and Nigeria fifth worst at 0.10 ). All three countries are also effectively dictatorships, with PC scores of 0.00 in 1975 and 1990. These EF changes and PC levels largely explain their inability to attract foreign investment. For further illustration, suppose that Iran, Nigeria, and Syria had the same 1975-90 increases in EF and PC as South Korea (1.1 and 0.48 units, respectively). According to the estimated coefficients from model (7), Iran would have more than doubled technical efficiency from 0.330 to 0.675 , Nigeria would have increased technical efficiency from 0.615 to 0.88 , and Syria would have almost doubled technical efficiency from 0.671 to 1.127 . (Syria would have an output-input ratio beyond what is feasible for any members of the current sample!)

Another example illustrates our point that both PC and EF are necessary for productivity growth. Both Argentina and Peru experienced substantial increases in PC over the sample period, 0.41 units for Argentina (third best in the sample) and 0.38 units for Peru (fourth best). However, both had below-average increases in EF of 0.3 units. Despite these increases in PC, Argentina and Peru experienced technical efficiency declines of $1.61 \%$ (fifth worst) and $2.51 \%$ (third worst), respectively. Policy constraints are important, but only if current policies leave markets relatively free of government intervention.

\section{INDIVIDUAL COMPONENTS OF EF}

The composite measure of economic freedom provided by Gwartney et al. (2000) is derived from individual rankings of all countries in 23 specific areas. To be sure our results using the composite measure were not driven by Gwartney et al.'s (2000) particular aggregation method, we reestimated our results using individual components of EF in place of the composite measure. Besides constituting a robustness check for the results presented, this approach helps shed light on those specific policies most conducive to economic development. $^{14}$

Of the 23 individual components provided by Gwartney et al. (2000), 10 were available for

14. Other papers focusing on the individual components of the Gwartney et al. (2000) index include Ayal and Karras (1998), Carlsson and Lundström (2002), and Dawson (2002). 
all our sample countries in all four years. ${ }^{15} \mathrm{We}$ thus reestimated the technical inefficiency component of our production frontier as

$$
u_{i t}=\delta_{0}+\delta_{1} P C_{i t}+\sum_{j=2}^{12} \delta_{j} z_{j i t}+w_{i t},
$$

where $z_{j i t}$ represents country $i$ 's score in year $t$ on the following $j$ components $z_{j}$ :

1. $z_{2}$, the difference between the annual growth rate of the money supply (M1) and the annual growth rate of potential real GDP;

2. $z_{3}$, government consumption as a percent of total consumption;

3. $z_{4}$, government-consumption-to-totalconsumption squared (used for reasons explained later);

4. $z_{5}$, the presence and role of stateoperated enterprises (SOEs) (a higher rating means that government enterprises play a less significant role);

5. $z_{6}$, the right to own foreign currency domestically (zero or ten);

6. $z_{7}$, the freedom to engage in capital (investment) transactions with foreigners (zero, two, five, eight, or ten);

7. $z_{8}$, the right to own a bank account abroad (zero or ten);

8. $z_{9}$, the use of conscripts to obtain military personnel (zero or ten);

9. $z_{10}$, the average tax rate on international trade;

10. $z_{11}$, actual size of trade sector (imports and exports as a percentage of GDP) compared to the expected size; and

11. $z_{12}$, the difference between the official exchange rate and the black-market rate. ${ }^{16}$

Results are presented in Table 4. As in the model with the composite measure of EF, the coefficient on PC is negative and significant, indicating that countries with strong $\mathrm{PC}$ are less inefficient than countries with weak PC. All components of EF except the two

15. Gwartney et al. (2000) use alternative weights to construct the composite measure of EF for country-years in which one or more of the individual components of EF is missing. First, they try to construct a rating in each of the four major areas (money and inflation, government operations and regulations, takings and discriminatory taxation, and international exchange). For example, suppose an area consists of three components. They calculate an area rating if at least two of the three components exist by allocating the missing component's weight to the two available components. Next, they use a similar process to construct the composite rating from the area ratings.

16. Gwartney et al. (2000) express all rankings on ordinal scales. For greater precision, we have substituted for $z_{2}$ $z_{6}, z_{9}, z_{10}$, and $z_{11}$ the actual numbers. international trade proxies are statistically significant, and most have the expected signs.

The coefficient on $z_{2}$, inflation, is positive and significant, consistent with a substantial empirical literature showing that high inflation rates inhibit trade and capital formation by distorting relative prices (Aarstol, 1996; Kaul

\section{TABLE 4}

Effects of Individual Components of Economic Freedom

\begin{tabular}{|c|c|c|}
\hline Parameter & Variable & \\
\hline$\beta_{0}$ & Constant & $\begin{array}{l}4.7220^{* * *} \\
(0.4980)\end{array}$ \\
\hline$\beta_{1}$ & Capital/worker & $\begin{array}{l}0.5980^{* * *} \\
(0.0540)\end{array}$ \\
\hline$\delta_{0}$ & Constant & $\begin{array}{l}0.9796^{* * *} \\
(0.1262)\end{array}$ \\
\hline$\delta_{1}$ & $\mathrm{PC}$ & $\begin{array}{c}-0.3237^{* * *} \\
(0.0639)\end{array}$ \\
\hline$\delta_{2}$ & Inflation & $\begin{array}{l}0.0006^{* * *} \\
(0.0001)\end{array}$ \\
\hline$\delta_{3}$ & Government spending & $\begin{array}{c}-0.0383^{* * *} \\
(0.0103)\end{array}$ \\
\hline$\delta_{4}$ & $\begin{array}{l}\text { (Government spending) } \\
\text { squared }\end{array}$ & $\begin{array}{l}0.0013^{* * *} \\
(0.0005)\end{array}$ \\
\hline$\delta_{5}$ & SOEs & $\begin{array}{l}-0.0544^{* * *} \\
(0.0108)\end{array}$ \\
\hline$\delta_{6}$ & Foreign money & $\begin{array}{c}-0.0082^{* *} \\
(0.0039)\end{array}$ \\
\hline$\delta_{7}$ & Foreign capital transactions & $\begin{array}{c}-0.0238^{* * *} \\
(0.0094)\end{array}$ \\
\hline$\delta_{8}$ & Foreign account & $\begin{array}{l}0.0185^{* * *} \\
(0.0047)\end{array}$ \\
\hline$\delta_{9}$ & Conscription & $\begin{array}{r}0.0082^{*} \\
(0.0052)\end{array}$ \\
\hline$\delta_{10}$ & Taxes on IT & $\begin{array}{c}0.0032 \\
(0.0037)\end{array}$ \\
\hline$\delta_{11}$ & Trade sector & $\begin{array}{c}0.0110 \\
(0.0508)\end{array}$ \\
\hline$\delta_{12}$ & Black-market premium & $\begin{array}{l}0.0002^{* * *} \\
(0.0001)\end{array}$ \\
\hline$\sigma^{2}$ & & $\begin{array}{l}0.0073^{* * *} \\
(0.0009)\end{array}$ \\
\hline$\gamma$ & Inefficiency indicator & $\begin{array}{l}0.9718^{* * *} \\
(0.0407)\end{array}$ \\
\hline Log-likelihood & & 228.425 \\
\hline
\end{tabular}

Notes: Maximum-likelihood estimates for stochastic production frontier with inefficiency component. Pooled data from 1975, 1980, 1985, and 1990. $N=156$. Country and year fixed effects not reported. Standard errors given in parentheses.

${ }^{* * *},{ }^{* *}$, and ${ }^{*}$ represent statistical significance at the $1 \%, 5 \%$, and $10 \%$ levels, respectively. 
and Seyhun, 1990; see also Scully, 1992). The coefficient on $z_{3}$, government expenditures, is significant but negative, indicating that countries with high government expenditures are less inefficient than countries with low government expenditures. This is surprising, given that most of the empirical growth literature finds a negative correlation between the size of the public sector and economic growth (Kormendi and Meguire, 1985; Landau, 1983), and it seems inconsistent with our laissez-faire argument. Some authors suggest that government expenditures on certain core functionsprotection of property rights, enforcement of contracts, and a legal system to resolve disputes, and possibly some goods like public infrastructure and education-stimulate economic growth (Gwartney et al., 1998, 16566). ${ }^{17}$ Barro (1990) develops a growth model in which the level of government expenditures contributes positively to economic growth up to a certain level (for example, $25 \%$ of GDP), but reduces growth beyond that level. Branson and Lovell (2000), following similar reasoning, estimate an optimal level of government spending for New Zealand of $22 \%$.

An alternative explanation for our coefficient on $z_{3}$, however, is that the level of government expenditures is likely to be a poor proxy for the role of government intervention in the economy. It is increasingly recognized that government activities such as statutes, administrative regulation, and the judicial interpretation of legal rules redirect resources as much as, or more than, taxes and spending (Peltzman, 1980; Lindbeck, 1985; Borcherding, 1985; Block, 1991). For this reason, recent research on the United States has used alternative measures of government intervention such as the number of pages in the Federal Register (Westley, 1998; see also Goff, 1996). More generally, as Higgs $(1987,29)$ points out, "all quantitative indexes of the size of government share a common defect: their changes may indicate either changes in the scope of effective governmental authority or merely changes in the level at which government operates within a constant scope of authority."

Nonetheless, to allow comparison of our results to those of similar studies, we follow

17. However, as emphasized by Rothbard (1970), Benson (1990, 1998), and others, even the "protective" functions of government such as securing law and order are also provided by markets.
Branson and Lovell (2000) and include a second-order term to solve for the level of government expenditures $(G O V)$ associated with minimum technical inefficiency. We model the inefficiency component as

$$
u=\delta_{0}+\delta_{3} G O V+(1 / 2) \delta_{4} G O V^{2}
$$

(abstracting from the other independent variables and omitting time and country subscripts). This implies that

$$
\partial u / \partial G O V=\delta_{3}+\delta_{4} G O V .
$$

The theory that government spending up to a certain level is beneficial implies that $\delta_{3}$ should be negative and $\delta_{4}$ positive. Setting that expression equal to zero yields the "optimal" $G O V$ equal to $-\delta_{3} / \delta_{4}$. As Table 2 shows, $\delta_{4}$ is positive and significant, suggesting an optimal GOV of about $30 \%$, somewhat higher than Branson and Lovell's figure. ${ }^{18}$

Consistent with our overall position, the coefficient on $z_{5}$, the presence and role of SOEs, is negative and significant. (Recall that a higher score on $z_{5}$ indicates a smaller role for SOEs.) The empirical literature on privatization strongly suggests that SOEs are less efficient than private-sector benchmarks (Boardman and Vining, 1989; Ehrlich et al., 1994; Majumdar, 1996; Dewenter and Malatesta, 2001; see also Megginson and Netter, 2001). Like this literature, we find that aggregate economic performance is lower when SOEs play a more important role.

The results on the remaining variables are mixed. The negative coefficients on $z_{6}$, the right to own foreign currency domestically, and $z_{7}$, the freedom to engage in capital transactions with foreigners, support the claim that these liberties enhance productivity by encouraging foreign trade. On the other hand, the positive coefficient on $z_{8}$, the right to own foreign bank accounts, does not appear to support our argument, unless foreign accounts are regarded as repositories of illegal gains that would have otherwise been invested domestically. The coefficient on $z_{9}$, conscription, is positive and significant at the $10 \%$ level, suggesting that forced military service is less efficient than voluntary arrangements.

18. Our GOV measures government consumption relative to total consumption, not government expenditures relative to GDP, so our measure is not directly comparable to theirs. 
Finally, the coefficients on $z_{10}$ and $z_{11}$, the two variables that relate directly to international trade, are not statistically significant. Despite arguments that trade barriers can increase productivity by correcting factormarket distortions, protecting infant industries, and so on, it is generally agreed that free trade should produce efficiency gains from improved resource allocation due to specialization according to comparative advantage. Most empirical studies find that openness to trade, usually proxied by the ratio of exports or imports to real GDP, has a significant positive (but small) impact on growth (see, for example, Feder, 1983; Kormendi and Meguire, 1985). However, our model fails to pick up a significant effect. Possibly neither variable is a good measure of a country's openness to trade; Ayal and Karras (1998) also find that the average tax rate on international trade is not a significant determinant of economic growth in a neoclassical framework. ${ }^{19}$ An ideal measure of trade liberalization would be an aggregate, weighted index of the divergence between world and domestic prices; unfortunately, such a measure has not yet been constructed. We do find that the coefficient on $z_{12}$, the blackmarket exchange premium, is positive and significant (countries with high premiums are less efficient). The black-market premium is usually used as a measure of distortions on foreign trade, but may also be interpreted more generally as a proxy for other distortionary policies and for macroeconomic instability.

In general, these results in this section support our hypothesis that EF and PC raise technical efficiency even if we employ components of $\mathrm{EF}$ instead of a composite measure of EF. Our basic conclusion is thus robust to the precise measurement of EF.

\section{ENDOGENEITY}

Clearly, then, the institutional environment, as captured by EF and PC, is highly correlated with technical efficiency. However, we have not

19. One potential problem with $z_{10}$, the average tax on international trade, is that it is strongly correlated with percapita GDP (Easterly and Rebelo, 1993). Less developed countries tend to rely heavily on tariffs because they lack the administrative ability to collect other types of taxes. To see if the inclusion of $z_{10}$ had biased the coefficients on the remaining right-hand-side variables, we reestimated the regression reported in Table 4 without $z_{10}$. The point estimates and significance levels for the remaining variables were essentially the same as those reported in Table 4. yet established a causal relation between institutions and efficiency. So far we have treated $\mathrm{EF}$ and $\mathrm{PC}$ as determinants of productivity. Conceivably, the relationship could go the other way: countries that are more productive are wealthier, and wealthy countries can afford to have stable, laissez-faire policies. This could be the underlying causal explanation for our results.

In a historical context, this argument makes little sense. Countries with interventionist, unstable policies did not become rich and then suddenly reduce the sizes of their public sectors and stick to established rules of the game. Rather, it was the stable, laissez-faire economies that became wealthy in the first place (Rosenberg and Birdzell, 1986; Landes, 1998). Nonetheless, to explore the possibility that our results reflect a causal relationship from wealth to $\mathrm{EF}$ and $\mathrm{PC}$, we estimated panel regressions of $\mathrm{EF}$ and $\mathrm{PC}$ on real GDP per worker and real GDP per worker lagged one period. Results from both random-effects and fixed-effects regressions are presented in panel A of Table 5. As seen in the table, the coefficients on real GDP per worker are positive and highly significant in both EF regressions and positive in both PC regressions (though significant only in the random-effects model). This means that income is contemporaneously correlated with both dependent variables. However, lagged real GDP per worker is not significant in any regression. Controlling for current income, then, past values of income are not good predictors of EF or PC.

By contrast, as seen in panel B of Table 5, lagged values of $\mathrm{EF}$ and $\mathrm{PC}$ are generally good predictors of real GDP per worker, controlling for current values of EF and PC. These findings suggest that $\mathrm{EF}$ and $\mathrm{PC}$ are best understood as drivers of productivity, not simply consequences of economic well-being. Gwartney et al. (1999) also look at whether growth causes EF. They find that the value of the composite measure of EF in a year, and the change in EF over time, affect growth over a period of decades. However, they find no correlation between economic growth and future changes in EF. In other words, higher growth in the present is not correlated with higher levels of EF in the future. Dawson (2003) applies Granger causality testing to individual components of EF and finds that strong property rights and relatively unfettered markets are primary drivers of growth, whereas other 
TABLE 5

Endogeneity

\begin{tabular}{|c|c|c|c|c|}
\hline \multicolumn{5}{|c|}{ A. Effects of income on economic freedom and policy constraints } \\
\hline Dependent variable & $\mathrm{EF}$ & $\mathrm{EF}$ & $\mathrm{PC}$ & PC \\
\hline Constant & $\begin{array}{l}3.267870^{* * *} \\
(0.359108)\end{array}$ & - & $\begin{array}{c}0.116441^{* *} \\
(0.058716)\end{array}$ & - \\
\hline RGDP/worker & $\begin{array}{l}0.000114^{* * *} \\
(0.000036)\end{array}$ & $\begin{array}{l}0.000132^{* * *} \\
(0.000040)\end{array}$ & $\begin{array}{l}0.000021^{* * *} \\
(0.000007)\end{array}$ & $\begin{array}{c}0.000006 \\
(0.000008)\end{array}$ \\
\hline Lagged RGDP/worker & $\begin{array}{c}-0.000023 \\
(0.000039)\end{array}$ & $\begin{array}{c}0.000046 \\
(0.000046)\end{array}$ & $\begin{array}{c}0.000002 \\
(0.000008)\end{array}$ & $\begin{array}{c}-0.000001 \\
(0.000009)\end{array}$ \\
\hline Fixed effects? & No & Yes & No & Yes \\
\hline Adjusted $R^{2}$ & 0.734 & 0.832 & 0.783 & 0.865 \\
\hline \multicolumn{5}{|c|}{ B. Effects of economic freedom and policy constraints on income } \\
\hline Dependent variable & RGDP/worker & RGDP/worker & RGDP/worker & RGDP/worker \\
\hline Constant & $\begin{array}{l}5001.6^{* * *} \\
(2077.2)\end{array}$ & - & $\begin{array}{l}10731.4^{* * *} \\
(1422.4)\end{array}$ & - \\
\hline $\mathrm{EF}$ & $\begin{array}{l}1221.0^{* * *} \\
(266.8)\end{array}$ & $\begin{array}{l}1146.3^{* * *} \\
(272.9)\end{array}$ & - & - \\
\hline Lagged EF & $\begin{array}{l}1545.4^{* * *} \\
(290.3)\end{array}$ & $\begin{array}{l}1468.0^{* * *} \\
(298.0)\end{array}$ & - & - \\
\hline $\mathrm{PC}$ & - & - & $\begin{array}{l}6268.8^{* * *} \\
(1760.4)\end{array}$ & $\begin{array}{c}1560.6 \\
(1978.0)\end{array}$ \\
\hline Lagged PC & - & - & $\begin{array}{l}8228.1^{* * *} \\
(1975.4)\end{array}$ & $\begin{array}{l}-142.4 \\
(2537.5)\end{array}$ \\
\hline Fixed effects? & No & Yes & No & Yes \\
\hline Adjusted $R^{2}$ & 0.959 & 0.973 & 0.858 & 0.912 \\
\hline
\end{tabular}

Notes: OLS regressions with pooled data from 1975, 1980, 1985, and 1990. $N=117$. Random-effects models include a constant term. Standard errors given in parentheses. RGDP denotes real GDP.

${ }^{* * *},{ }^{* *}$, and ${ }^{*}$ represent statistical significance at the $1 \%, 5 \%$, and $10 \%$ levels, respectively.

components of EF, such as the size of government and controls on international finance, are more likely the result of growth. (Yet other components, such as those related to monetary and price stability, appear to be jointly determined with growth.) Along with these results, our findings reported in Table 5 support the idea that the institutional environment is an important determinant of economic performance, not merely its consequence.

\section{CONCLUSIONS}

Economists have become increasingly aware that technology, and not resource endowment, is usually the most important driver of economic performance over time. Our analysis shows that cross-country differences in technical efficiency need not be treated as exogenous - indeed, these differences can themselves be explained largely by differences in institutional environments. Countries with legal and regulatory frameworks that promote trade and competition and relatively stable political systems tend to be closest to the best-practice frontier.

More generally, our findings for the 197590 period complement the modern literature on long-term economic performance. Recent work in economic history argues that the emergence of long-distance trade and, later, industrialization, were dependent on political and social institutions. In early societies, agency problems were typically solved through kinship or other close social ties. Greif (1989), for example, shows how 11th-century Jewish traders in the Mediterranean area enforced codes of conduct by maintaining close social relationships, using the threat of ostracism as a disciplinary device. Later, standardized weights and measures, units of account, media of exchange, and procedures to resolve disputes (such as merchant law courts) 
supported the expansion of trade by lowering information costs. Capital markets could flourish only in societies where rulers could credibly commit not to expropriate private wealth; North and Weingast (1989) show how capital markets emerged in Britain after the Glorious Revolution of 1688 placed parliamentary limits on the authority of the Crown. The growth of product and factor markets depends similarly on establishing secure property rights. Furthermore, as an economy industrializes, more commercial activity involves transacting: trade, finance, banking, insurance, and management (Wallis and North, 1986). Industrialization requires institutions to mitigate the costs associated with these transactions.

A key to understanding economic development, then, is institutional development. "The central issue of economic history and of economic development is to account for the evolution of political and economic institutions that create an economic environment that induces increasing productivity" (North, 1991, 98). In future work we hope to study the evolution of institutions that promote technical efficiency, rather than taking institutions as exogenous as we do in the present article. We also hope to incorporate measures of financial market development, though this raises potential endogeneity problems. A further issue concerns the relationship between changes in PC and changes in EF over time. Is the change in one of these variables a necessary precondition to a change in the other? Our sample includes countries that experienced increases in PC without corresponding increases in EF, and failed to enjoy efficiency gains as a result. However, there are no similar examples of countries that experienced an increase in EF without corresponding increases in $\mathrm{PC}$, suggesting that a change in $\mathrm{PC}$ tends to precede a change in $\mathrm{EF}$. Further work on the comovement of these variables over time may provide valuable guidance for economic reform in the developing and postcommunist world.

In short, we are convinced that productivity analysis can benefit from closer study of political and regulatory institutions, and that the new institutional economics can benefit from more explicit theorizing about the channels through which institutional factors affect aggregate economic performance. We look forward to future research that combines these two strands of literature.
APPENDIX TABLE A1

List of Countries

\begin{tabular}{ll}
\hline Argentina & Mauritius \\
Australia & Mexico \\
Austria & Netherlands \\
Belgium & New Zealand \\
Bolivia & Nigeria \\
Canada & Norway \\
Chile & Peru \\
Denmark & Philippines \\
Finland & Portugal \\
France & Spain \\
Germany & Sweden \\
Greece & Switzerland \\
Guatemala & Syria \\
India & Taiwan \\
Iran & Thailand \\
Israel & Turkey \\
Italy & United Kingdom \\
Japan & United States \\
Kenya & Venezuela \\
Korea & \\
\hline
\end{tabular}

\section{REFERENCES}

Aarstol, M. "The Impact of Inflation upon Capital Markets and Growth.” Ph.D. dissertation, Stanford University, 1996.

Aigner, D., C. A. K. Lovell, and P. Schmidt. "Formulation and Estimation of Stochastic Frontier Production Function Models." Journal of Econometrics, 6, 1977, 21-37.

Ali, A. M., and W. M. Crain. "Institutional Distortions, Economic Freedom and Growth." Cato Journal, 21(3), 2002, 415-26.

Ayal, E. B., and G. Karras. "Components of Economic Growth and Growth: An Empirical Study.” Journal of Developing Areas, 32, 1998, 327-38.

Baltagi, B. H., and J. M. Griffin. "A General Index of Technical Change." Journal of Political Economy, 96(1), 1988, 20-41.

Barro, R. J. "Government Spending in a Simple Model of Endogenous Growth.” Journal of Political Economy, 98(5), 1990, 103-26.

- "Economic Growth in a Cross Section of Countries." Quarterly Journal of Economics, 106, 1991, 407-43.

Battese, G. E., and T. J. Coelli. "A Stochastic Frontier Production Function Incorporating a Model for Inefficiency Effects." Working Papers in Econometrics and Applied Statistics no. 69, Department of Econometrics, University of New England, Armidale, 1993.

. "A Model for Technical Inefficiency Effects in a Stochastic Frontier Production Function for Panel Data." Empirical Economics, 20(2), 1995, 325-32.

Benson, B. L. The Enterprise of Law: Justice without the State. San Francisco: Pacific Research Institute for Public Policy Research, 1990. 
To Serve and Protect: Privatization and Community in Criminal Justice. New York: New York University Press, 1998.

Block, W. Economic Freedom: Toward a Theory of Measurement. Vancouver: Fraser Institute, 1991.

Boardman, A., and A. R. Vining. "Ownership and Performance in Competitive Environments: A Comparison of the Performance of Private, Mixed, and StateOwned Enterprises." Journal of Law and Economics, 32, 1989, 1-33.

Borcherding, T. E. "The Causes of Government Expenditure Growth: A Survey of the U.S. Evidence.” Journal of Public Economics, 28, 1985, 359-82.

Branson, J., and C. A. K. Lovell. "Taxation and Economic Growth in New Zealand." In Taxation and the Limits of Government, edited by G. W. Scully and P. J. Caragata Boston: Kluwer Academic Publishers, 2000.

Carlsson, F., and S. Lundström. "Economic Freedom and Growth: Decomposing the Effects." Public Choice, 112(3), 2002, 335-44.

Coelli, T. J. "A Guide to FRONTIER Version 4.1: A Computer Program for Frontier Production Function Estimation.” CEPA Working Paper 96/07, Department of Econometrics, University of New England, Armidale, 1996.

Dawson, J. W. "Institutions, Investment, and Growth: New Cross-Country and Panel Data Evidence." Economic Inquiry, 36, 1998, 603-19.

_. "Causality in the Freedom-Growth Relationship." European Journal of Political Economy, 2003, forthcoming.

Dewenter, K., and P. H. Malatesta. "State-Owned and Privately Owned Firms: An Empirical Analysis of Profitability, Leverage, and Labor Intensity." American Economic Review, 91(1), 2001, 320-34.

Drobak, J. N., and J. V. Nye. The Frontiers of the New Institutional Economics. San Diego: Harcourt Brace, 1997.

Easterly, W., and S. Rebelo. "Fiscal Policy and Economic Growth: An Empirical Investigation." Journal of Monetary Economics, 32(3), 1993, 417-58.

Easton, S. T., and M. A. Walker. "Income, Growth, and Economic Freedom." American Economic Review, 87(2), 1997, 328-32.

Ehrlich, I., G. Gallais-Hamonno, Z. Liu, and R. Lutter. "Productivity Growth and Firm Ownership: An Empirical Investigation." Journal of Political Economy, 102, 1994, 1006-38.

Feder, G. "On Exports and Economic Growth." Journal of Development Economics, 12(1/2), 1983, 59-73.

Fried, H. O., C. A. K. Lovell, and S. S. Schmidt, eds. The Measurement of Productive Efficiency: Techniques and Applications. New York: Oxford University Press, 1993.

Friedman, M. Capitalism and Freedom. Chicago: University of Chicago Press, 1962.

Furubotn, E. G., and R. Richter. Institutions and Economic Theory: The Contribution of the New Institutional Economics. Ann Arbor: University of Michigan Press, 1997.

Gastil, R. D. Freedom in the World. Westport, CT: Greenwood Press, 1982.

Goff, B. Regulation and Macroeconomic Performance. Boston: Kluwer, 1996.
Greif, A. "Reputation and Coalitions in Medieval Trade: Evidence on the Maghribi Traders." Journal of Economic History, 49, 1989, 857-82.

Gwartney, J., and R. Lawson, with D. Samida. Economic Freedom of the World: 2000 Annual Report. Vancouver: Fraser Institute, 2000. Data retrieved online from www.freetheworld.com.

Gwartney, J., R. Holcombe, and R. Lawson. "The Scope of Government and the Wealth of Nations." Cato Journal, 18, 1998, 163-90.

Gwartney, J., R. Lawson, and R. Holcombe. "Economic Freedom and the Environment for Economic Growth." Journal of Institutional and Theoretical Economics, 155(4), 1999, 643-63.

Hayek, F. A. The Road to Serfdom. Chicago: University of Chicago Press, 1944.

Henisz, W. J. "The Institutional Environment for Economic Growth." Economics and Politics, 12(1), 2000a, 1-32.

. "The Institutional Environment for Multinational Investment." Journal of Law, Economics and Organization, 16(2), 2000b, 334-64.

Henisz, W. J., and B. A. Zelner. "The Institutional Environment for Telecommunications Investment." Journal of Economics and Management Strategy, 10(1), 2001, 123-48.

Higgs, R. Crisis and Leviathan: Critical Episodes in the Growth of American Government. New York: Oxford University Press, 1987.

Kaul, G., and H. N. Seyhun. "Relative Price Variability, Real Shocks, and the Stock Market." Journal of Finance, 45, 1990, 479-96.

King, R. G., and R. Levine. "Finance, Entrepreneurship, and Growth: Theory and Evidence." Journal of Monetary Economics, 32(3), 1993a, 513-42.

"Finance and Growth: Schumpeter Might Be Right." Quarterly Journal of Economics, 108(3), 1993b, 717-37.

. "Financial Intermediation and Economic Development." In Financial Intermediation in the Construction of Europe, edited by C. Mayer and X. Vives. London: Centre for Economic Policy Research, 1993c, pp. 156-89.

Klein, P. G. "New Institutional Economics." In Encyclopedia of Law and Economics, edited by B. Bouckeart and G. De Geest. Cheltenham, UK: Edward Elgar, 2000, pp. 456-89.

Kormendi, R. C., and P. G. Meguire. "Macroeconomic Determinants of Growth: Cross-Country Evidence." Journal of Monetary Economics, 16(2), 1985, 141-63.

Krugman, P. "The Myth of Asia's Miracle." Foreign Affairs, 76(3), 1994, 62-78.

Landes, D. S. The Wealth and Poverty of Nations: Why Some Are So Rich and Some So Poor. New York: Norton, 1998.

Landau, D. L. "Government Expenditure and Economic Growth: A Cross-Country Study." Southern Economic Journal, 49(3), 1983, 783-92.

La Porta, R., F. Lopez-de-Silanes, A. Shleifer, and R. Vishny. "The Quality of Government." Journal of Law, Economics and Organization, 15, 1999, 222-79.

Levine, R. "Financial Development and Economic Growth: Views and Agenda." Journal of Economic Literature, 35, 1997, 688-726. 
Lindbeck, A. "Redistribution Policy and the Expansion of the Public Sector." Journal of Public Economics, 28, 1985, 309-28.

Majumdar, S. K. "Assessing Comparative Efficiency of the State-Owned, Mixed, and Private Sectors in Indian Industry." Public Choice, 96, 1996, 1-24.

Meeusen, W., and J. van den Broeck. "Efficiency Estimation from Cobb-Douglas Production Functions with Composed Error." International Economic Review, 18, 1977, 435-44.

Megginson, W. L., and J. M. Netter. "From State to Market: A Survey of Empirical Studies on Privatization." Journal of Economic Literature, 39, 2001, 321-89.

Mises, L. von. Liberalism: In the Classical Tradition. 1927; Irvington-on-Hudson, NY: Foundation for Economic Education, 1985

North, D. C. Institutions, Institutional Change and Economic Performance. Cambridge: Cambridge University Press, 1990.

."Institutions." Journal of Economic Perspectives, 5, 1991, 97-112.

North, D. C., and R. P. Thomas. The Rise of the Western World: A New Economic History. Cambridge: Cambridge University Press, 1973.

North, D. C., and B. R. Weingast. "Constitution and Commitment: The Evolution of Institutions Governing Public Choice in 17th Century England." Journal of Economic History, 49, 1989, 803-32.

Norton, S. W. "Poverty, Property Rights, and Human Well-Being: A Cross-National Study." Cato Journal, 18(2), 1998, 233-45.

Nuxoll, D. A. "Differences in Relative Prices and International Differences in Growth Rates." American Economic Review, 84(5), 1994, 1423-36.

Peltzman, S. "The Growth of Government." Journal of Law and Economics, 23, 1980, 209-87.
Rosenberg, N., and L. E. Birdzell Jr. How the West Grew Rich: The Economic Transformation of the Industrial World. New York: Basic Books, 1986.

Rothbard, M. N. Power and Market: Government and the Economy. Kansas City: Sheed Andrews and McMeel, 1970.

Scully, G. W. "The Institutional Framework and Economic Development.” Journal of Political Economy, 96(3), 1988, 652-62.

- Constitutional Environments and Economic Growth. Princeton, NJ: Princeton University Press, 1992.

Summers, R., and A. Heston. "The Penn World Table (Mark V): An Expanded Set of International Comparisons 1950-1988." Quarterly Journal of Economics, 106, 1991, 327-68.

Temple, J. "The New Growth Evidence." Journal of Economic Literature, 37(1), 1999, 112-56.

Wallis, J. J., and D. C. North. "Measuring the Transaction Sector in the American Economy, 1870-1970." In Income and Wealth: Long-Term Factors in American Economic Growth, edited by Stanley Engerman and Robert Gallman. Chicago: University of Chicago Press, 1986.

Westley, C. "Government Regulation and Income Inequality in the United States, 1970-1990." Applied Economics Letters, 5, 1998, 805-8.

World Bank. The East Asian Miracle: Economic Growth and Public Policy. New York: Oxford University Press, 1993.

Young, A. "Lessons from the East Asian NICs: A Contrarian View." European Economic Review, 38, 1994, 964-73. 